\title{
Distribution and Growth of Larval Rainbow Smelt in Eastern Lake Michigan, 1978-1981
}

\author{
Heang T. Tin and David J. Jude \\ Great Lakes Research Division, University of Michigan \\ Ann Arbor, Michigan 48109
}

\begin{abstract}
Distribution and growth of rainbow smelt Osmerns mordax larvae are described from samples collected in eastern Lake Michigan during 1978-1981 with plankton nets and benthic sleds deployed in water $1-15 \mathrm{~m}$ deep. Rainbow smelt larvae less than $25.5 \mathrm{~mm}$ total length were caught from May to early August, whereas young of the year $25.5 \mathrm{~mm}$ and larger occurred from July to September. Newly hatched larvae were found mostly during May; however, some hatchjng occurred in late June or early July, apparently due to slower incubation of eggs in deep cooler water. After hatching, rainbow smelt larvae were distributed in shallow water for a short period; from June to early August larvae were widely dispersed. Larvae concentrated inshore in late August. They generally were found at a few random depth strata from May to early August. In late August larvae concentrated near bottom. Larval rainbow smelt were most common at water temperatures of 10 to $16 \mathrm{C}$. Rainbow smelt averaged from 5.3 to $6.1 \mathrm{~mm}$ in May; they grew to a mean length of $15.7 \mathrm{~mm}$ after 1 month and to $36.5-41.1 \mathrm{~mm}$ after 3 months.

Received January 4, 1982

Accepted April 14, 1983
\end{abstract}

Rainbow smelt Osmerus mordax is one of the most abundant species in the Great Lakes. It was introduced into eastern Lake Michigan from adjacent Crystal Lake in 1912 (Van Oosten 1940). Rainbow smelt spawn from March to May (Van Oosten 1940; Rupp 1959). Eggs hatch in 8 days at a mean water temperature of $15 \mathrm{C}$ (Cooper 1978) and in 29 days at 6-7 C (McKenzie 1964). Marine forms migrate upstream to spawn. Landlocked populations spawn in shallow areas of lakes or in tributary streams. Larvae originating upstream are carried immediately to lakes or estuaries (Rupp 1968).

The purpose of this study was to describe the distribution and growth of early life stages of rainbow smelt at a site along the eastern shore of Lake Michigan. Distribution of larval rainbow smelt in Lake Erie has been documented (MacCallum and Regier 1970), but only a few power-plant researchers (Jude ${ }_{1}$ et al. 1979; Jude $_{2}$ et al. 1979; Jude et al. 1980; Liston et al. 1980) and Wells (I973) have collected data on this species in eastern Lake Michigan. Rainbow smelt is an introduced marine exotic with the potential for disrupting the Lake Michigan ecosystem. Rainbow smelt has been suspected of adversely affecting lake herring Coregonus artedii populations in the Great Lakes (Wells and McLain 1973; Christie 1974) and was documented feeding on lake herring young in Lake
Superior (Selgeby et al. 1978). Our data will contribute to the understanding of the interactions of rainbow smelt larvae with the above species and other native fish in Lake Michigan, will aid in future decisions on water intake siting along this shore, and will provide needed information on one of the important salmonid forage species for modelling efforts similar to those of Stewart et al. (1982). This work was part of the 1978-1981 investigations of fish populations in the vicinity of the J. H. Campbell electricity-generating plant located near Port Sheldon, Ottawa County, Michigan.

\section{Methods}

Stations were located on the eastern shore of Lake Michigan, approximately $20 \mathrm{~km}$ south of Grand Haven, Michigan. Sampling occurred where bottom contours were $1,1.5,3,6,9,12$, and $15 \mathrm{~m}$ deep. Samples were taken from one stratum above bottom at the $1-$ and $1.5-\mathrm{m}$ stations, two strata above bottom at the 3-m station, four strata at the 6-m station, and five strata at each of the 9-, 12-, and 15-m stations; the bottom stratum was also sampled at all stations. Single samples were collected from all strata except the surface stratum of the $1-\mathrm{m}$ station where samples were duplicated.

Strata above bottom were sampled with a $0.5-\mathrm{m}$ diameter nylon plankton net of $363-\mu \mathrm{m}$ - 
aperture mesh. To collect samples at the 1-m station, two people hand-towed the plankton net near the surface while wading along the beach for a distance of approximately $61 \mathrm{~m}$. At all other above-bottom strata the plankton net was towed 5 minutes horizontally from a boat at a speed of approximately $250-500 \mathrm{~m} / 5 \mathrm{~min}$ utes. A flowmeter attached to the center of the net measured volume of water filtered. Approximately $45 \mathrm{~m}^{3}$ of water were filtered during most tows. Bottom strata were sampled with a sled (Yocum and Tesar 1980) towed for 5 minutes at each station, generally within 1 day of the plankton-net sampling.

Samples were collected during day (II001800 hours) and at night (2200-0300 hours). All samples were preserved in $10 \%$ buffered formalin. Rainbow smelt larvae sorted from the samples were measured to the nearest $0.1 \mathrm{~mm}$ total length (TL). Collections were made on nine occasions (mostly at 2- to 3-week intervals) between mid-April and mid-September, 19781981. An additional collecting trip was made during early May 1981. Surface, mid-depth, and bottom temperatures were taken at each station when sampling was performed.

All tows other than surface tows probably captured rainbow smelt larvae from higher strata when the nets were raised to the surface. Because of low volume of water filtered during the vertical haul of nets, contamination of samples by larvae from upper strata was considered negligible. Mean densities for each sampling period were calculated for the shallow water $(1$, 1.5 , and $3 \mathrm{~m})$, intermediate depths (6 and $9 \mathrm{~m})$, and deep water $(12$ and $15 \mathrm{~m})$; these were averages of densities in the vertical strata overlying these combinations of depth contours. Because large rainbow smelt larvae may avoid sampling gear during the day, only data from night samples were used to estimate densities during June, July, and August. Due to net avoidance by larger young-of-the-year rainbow smelt, mean length during August was calculated from young of the year collected in trawls (see Jude et al. 1981 for details) during the same sampling period. Length-frequency distributions $(0.5-\mathrm{mm}$ length intervals) were generated for larvae less than $25.5 \mathrm{~mm}$ TL; these are based on summed densities, rather than on numbers of larvae collected, to correct for unequal sampling efforts.

Analysis of variance was used to compare monthly day and night densities ( $\log _{10}$-transformed) of rainbow smelt larvae during May and June. Results were considered significant at $P \leqslant 0.05$. Differences in densities of larvae in the shallow water $(1-3 \mathrm{~m})$ and open water (6-15 m) were compared for mid-May and June; differences in densities at three temperature intervals $(10 \mathrm{C}$ and less, $10 . \mathrm{I}-14 \mathrm{C}$, and above $\mathrm{I} 4$ C) during May-August (all months pooled) were also examined by analysis of variance. Due to possible net avoidance by larger larvae during summer, only night data for June, July, and August were used in the analyses of variance. Day and night data collected in May were pooled to test the differences due to temperature and depth (shallow water, open water).

\section{Results}

May

Rainbow smelt larvae first were caught during mid-May 1978-I980 and early May I981 (Fig. 1); none were collected during April. Their mean lengths were $5.3-6.2 \mathrm{~mm}$ (Fig. 2). Average hatching length of rainbow smelt larvae is approximately $5 \mathrm{~mm}$ (McKenzie 1964). In weekly entrainment sampling in 1978-I980 at the Campbell Plant, which draws most of its cooling water from Lake Michigan, no rainbow smelt larvae were captured before I0 May (Jude et al. 1980), indicating that those collected during mid-May were among the first produced in the study area. During mid-May 1978 and early May I98I, rainbow smelt larvae were found mostly in shallow water ( $\mathrm{I}-3 \mathrm{~m})$ where spawning is known to occur (Rupp I959; Jude 2 et al. 1979). Mean densities in shallow water were 67 , 1, 41, and 17 larvae/1,000 $\mathrm{m}^{3}$ during mid-May $1978,1979,1980$, and 1981, respectively. During early May I98 I, mean density in shallow water was $57 \mathrm{I}$ larvae/ $\mathrm{I}, 000 \mathrm{~m}^{3}$. Rainbow sinelt larvae were scarce at intermediate depths (6 and $9 \mathrm{~m}$ ) and deep water ( 12 and $15 \mathrm{~m}$ ) during midMay 1978-1981. During May 1978, their mean density in shallow water was significantly higher $(P=0.05)$ than density in open water $(6-15 \mathrm{~m})$. No significant differences were found, however, between these two areas during mid-May 1979 and 1980. Rainbow smelt larvae generally occurred only at one or two depth strata sampled at each station and showed no particular pattern of vertical or diel distribution during May 1978-1981, as exemplified by the May 1979 


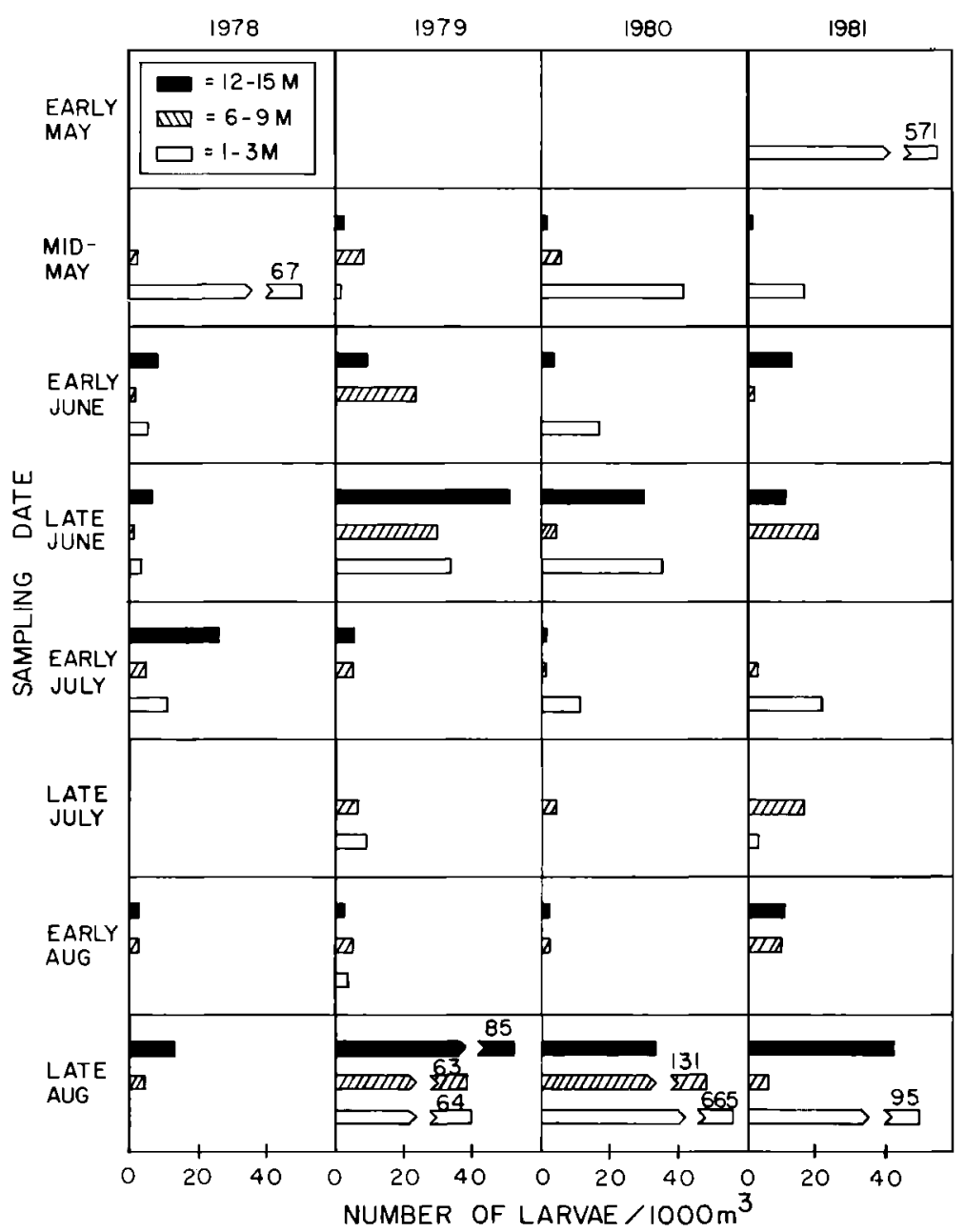

FIGURE 1.-Densities of larval rainbow smelt collected with plankton nets and sleds in eastern Lake Michigan, MayAugust 1978-1981. Data have been pooled for the water columns above three bottom-contour intervals.

data (Fig. 3). During May, differences between day and night densities over the 4 -year period were not significant.

\section{June}

During early June rainbow smelt larvae were widely scattered. Densities in shallow water, at intermediate depths, and in deep water were low, ranging from 0 to 24 larvae $/ 1,000 \mathrm{~m}^{3}$ (Fig. 1). Rainbow smelt larvae were $5.5-13 \mathrm{~mm}$ long. Few newly hatched larvae were found during early June 1978-1980 (Fig. 2). However, they were relatively common during early June 1981 , accounting for $68 \%$ of the larval rainbow smelt collected.
During late June, larvae $4.5-20 \mathrm{~mm}$ were found at most depths and were more common than during early June 1978-1980 (Fig. 1). Mean density ranges in shallow, intermediate, and deep water were, respectively, 0-35, 2-30, and 7-51 larvae $/ 1,000 \mathrm{~m}^{3}$ during late June $1978-$ 1981. Newly hatched individuals represented 30 to $60 \%$ of the larvae collected during late June 1978-1980 (Fig. 2). During late June 1979, rainbow smelt larvae were found at several strata in the water column day and night (Fig. 3).

Differences in densities between the shallow area $(1-3 \mathrm{~m})$ and open water $(6-15 \mathrm{~m})$ in June during 1978, 1979, and 1981 were not significant. During June 1980, the density in shallow 


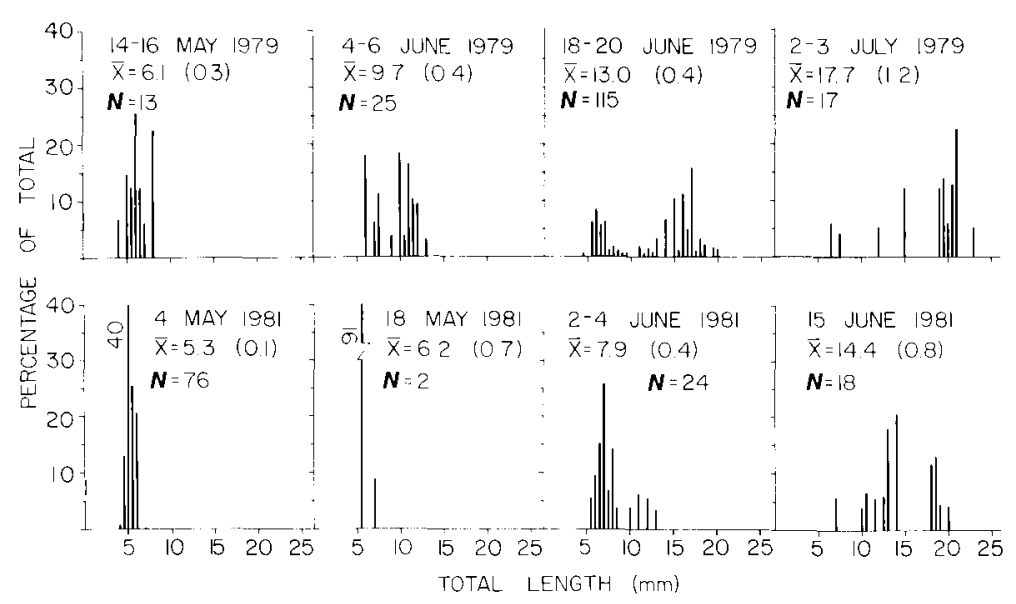

Figure 2.-Length-frequency histograms for larval rainbow smelt collected May-July, 1979 and 1981, in eastern Lake Michigan. Data were pooled over stations and diel period, and histograms represent calculated densities of larvae. $\overline{\mathrm{X}}=$ mean (SE); $\mathbf{N}=$ total number of larvae collected.

water was significantly higher $(P=0.001)$ than in open water. Day and night densities were not significantly different in June during the 4 -year period.

The length-frequency distribution of rainbow smelt larvae collected during late June was bimodal, suggesting that two hatching peaks occurred between early May and late June 19781980 (Fig. 2). The first mode included larvae $4.5-9.5 \mathrm{~mm}$, most being recently hatched larvae. The second mode included larvae $11.5-20$ $\mathrm{mm}$, most of which undoubtedly hatched during the second and third week of May. During 1981, due to relatively high water temperatures during spring, the first hatching peak occurred during early May and the second peak during early June (Fig. 2). Mean length of larvae from the early-May cohort was $15.7 \mathrm{~mm}$ during 18 20 June 1979. Mean length of the first cohort was not calculated for late June 1978, 1980, and 1981 because sample sizes were too small.

\section{July, August, and September}

From early July to early August, young-ofthe-year rainbow smelt were widely scattered in the study area (Fig. 1). Larva densities were generally low, ranging from 0 to 26 larvae/ 1,000 $\mathrm{m}^{3}$. During early July, larvae ranged from 6.5 to $29 \mathrm{~mm}$. Recently hatched larvae $(6.5-7.5 \mathrm{~mm})$ continued to occur during early July 1978-1980, but represented only a small percentage of total catches (Fig. 2). Larvae from the first cohort, which ranged from 19 to $29 \mathrm{~mm}$, comprised the major portion of larvae collected during early July 1979. During late July and early August 1978-1981, a few 24-47-mm fish, which probably belonged to the first cohort, were collected. Rainbow smelt $26-59 \mathrm{~mm}$ were caught in substantial numbers during late August (Fig. 1). Mean densities ranged from 6 to 665 larvae/ $1,000 \mathrm{~m}^{3}$ during late August 1979-1981 (they were substantially lower in 1978). Mean lengths were $36.5,36.7,40.0$, and $41.1 \mathrm{~mm}$, respectively, during late August 1978-1981. During late August 1979, young of the year were most common at deeper strata and near bottom, most being caught at night (Fig. 3). Catch of youngof-the-year rainbow smelt decreased appreciably during September.

During 1978-1981 we found larvae and larger young-of-the-year rainbow smelt in water temperatures from 5 to 23.3 C. Analyses of variance showed no significant fish-density differences among the three temperature intervals (10 C and less, 10.1-14 C, and above $14 \mathrm{C}$ ) during 1978 and 1980. Significantly higher densities were recorded at 10.1-14 $\mathrm{C}$ than at higher or lower temperature intervals during $1979(P=$ $0.04)$ and $1981(P=0.02)$.

\section{Discussion}

\section{Seasonal Distribution}

Timing of first occurrence of rainbow smelt larvae depends on water temperatures in spring. 


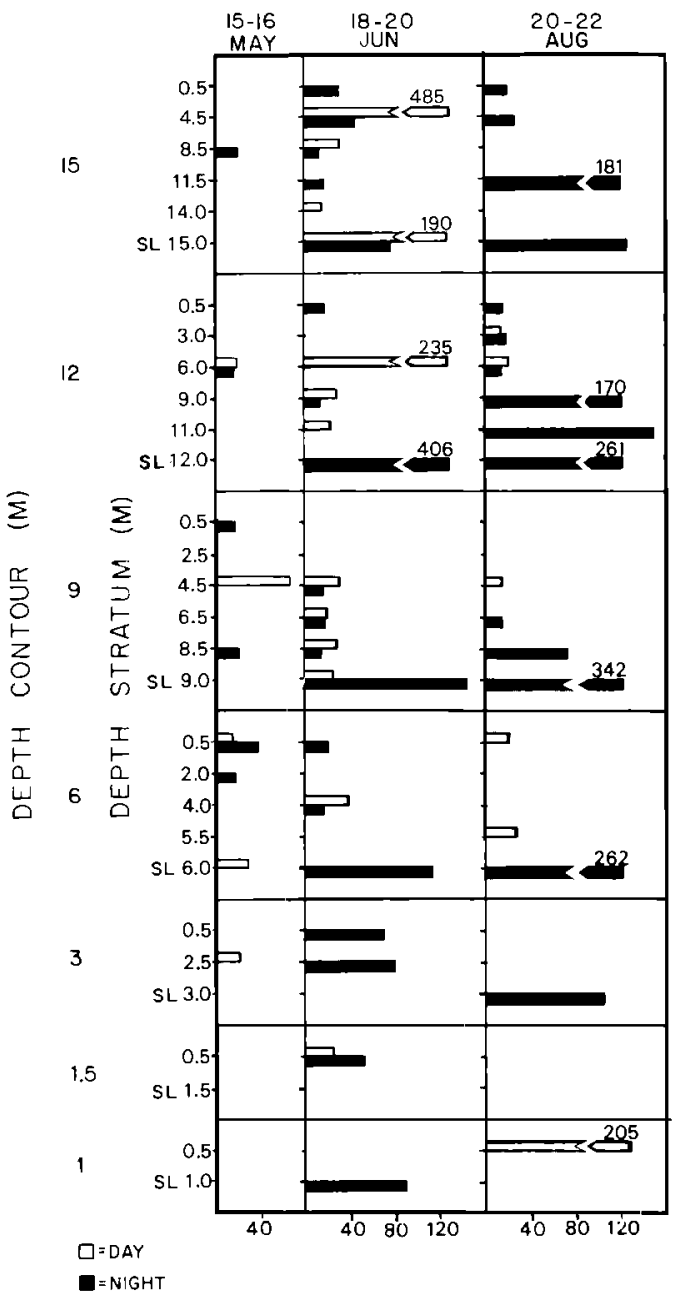

NUMBER OF LARVAE/1000 $\mathrm{M}^{3}$

FigURE 3.-Densities of larval rainbow smelt collected in plankton nets and sleds (SL) from 1-to 15-m depths in eastern Lake Michigan during May, June, and August 1979.

During 1978-1980 we first collected rainbow smelt larvae around mid-May, but they appeared earlier in May 1981, a year when inshore waters warmed faster than in the previous 3 years. For example, bottom temperatures taken between 9 and $12 \mathrm{~m}$ deep from 15 to 30 April were 3-5.7 C in $1978-1980$, but $6.8-8.4$ $\mathrm{C}$ in 1981. Near the Cook Plant ( $108 \mathrm{~km}$ south of the Campbell Plant), where water temperatures ranged from 7.4 to $12 \mathrm{C}$ during $18-24$ April 1974, rainbow smelt larvae were first collected during 2-3 May 1974 (Jude $_{2}$ et al. 1979).
Because the spawning season lasted only from mid-April to mid-May, based on inshore presence of ripe-running adults ( Jude $_{1}$ et al. 1979; Jude et al. 1980), late occurrence of newly hatched larvae into July probably resulted from slow incubation of eggs in colder water farther offshore. Length-frequency distributions of rainbow smelt during May-early July indicated that those hatching from early to mid-May 1978-1981 formed the predominant cohort.

High densities of rainbow smelt larvae generally occur in shallow water during May. $\mathrm{Jude}_{2}$ et al. (1979) and Liston et al. (1980) reported similar findings in other areas of eastern Lake Michigan. Although densities of rainbow smelt larvae during 14-16 May 1979 (5 larvae/1,000 $\mathrm{m}^{3}$ ) were relatively low, we think this was because our sampling did not coincide exactly with peak hatching and because newly hatched larvae were dispersed rapidly by water currents, not because there was a poor hatch in 1979.

Rainbow smelt larva densities were generally low from June to early August due to wide dispersal of larvae in Lake Michigan. Some increase in abundance may occur during late June due in part to the second hatching peak. In 1981, few newly hatched larvae were found during late June, probably because most late hatching that year took place around early June. Larger larvae from the first cohort also may have made up a substantial portion of rainbow smelt larvae collected during late June.

Density of young-of-the-year rainbow smelt in the study area substantially increased during late August, suggesting that most young of the year resided within the 15 -m contour. Youngof-the-year rainbow smelt were reported to move offshore during early fall (MacCallum and Regier 1970; Jude ${ }_{2}$ et al. 1979). The decrease in young-of-the-year abundance observed in the study area during September probably resulted from a similar offshore migration.

During May, rainbow smelt larvae were mostly small $(4-8 \mathrm{~mm})$ and probably were not able to avoid sampling gear. Net avoidance probably began by late June when larvae reached $20 \mathrm{~mm}$ TL. Despite their ability to avoid plankton nets as they grew older, young rainbow smelt were caught more frequently during late August than earlier, probably due to their increase in density.

Young-of-the-year rainbow smelt were reported to prefer water temperatures of 13-14 
C (Jude ${ }_{2}$ et al. 1979; Brandt et al. 1980). During 1979 and 1981 , in our study area, most rainbow smelt larvae were caught in similar water temperatures, as indicated by the significantly higher density at 10.1-14 G than at higher or lower temperature ranges. Substantial numbers of larvae also were collected in water temperatures of 14.1-16 C during June and August I979. During 1978 and 1980, rainbow smelt larvae were equally common at the three temperature intervals, suggesting that their distribution may be influenced at times by factors other than water temperature.

\section{Spatial Distribution}

Hatching of rainbow smelt eggs in eastern Lake Michigan apparently takes place in shallow water during May and in deep water during June and early July. Although rainbow smelt spawn in shallow water (Daly and Wiegert 1958; Rupp 1959; Jude ${ }_{2}$ et al. 1979), spawning may also take place in deep water (9-22 m) (Legault and Delisle 1968; MacCallum and Regier 1970; Owens 1982). During late April 1978 and midMay 1980, we collected a few rainbow smelt eggs with sleds at the bottom stratum of the $15-\mathrm{m}$ contour. Eggs that were deposited in shallow water mav be detached from the substrate and transported to deeper water by offshore currents. Rainbow smelt eggs dislodged from rubble may successfully hatch (Rupp 1965). All rainbow smelt eggs spawned in relatively warm water (8-13.5 C during 14-16 May, and 9.8-14 C during 4-6 June 1979) in shallow areas near the Campbell Plant probably hatched by the end of May. Because no rainbow smelt spawning was observed during June, based on seine and gill-net catches of adults (Jude et al. 1981), newly hatched larvae collected during June and early July probably hatched in deep water, where water was colder. Fertilized rainbow smelt eggs kept in an incubation chamber set on the bottom at $27.4 \mathrm{~m}$, in southeastern Lake Michigan in late April 1979, hatched after 59 days of incubation in water temperatures of 2.9-5.9 C (Owens 1982).

Rainbow smelt larvae were dispersed soon after hatching and generally remained widespread until early August. They were still abundant in the shallows of our study area during mid-May 1978, more dense there than in open water. They were found only in the shallow water during early May 1981. Water currents in the vicinity of the Campbell Plant vary from 0 to $0.3 \mathrm{~m} / \mathrm{second}$ over a period of several days (Liston and Tack 1976), suggesting that larvae do not remain at the hatching site more than several days after hatching. Rainbow smelt larvae already were dispersed to deeper water during mid-May 1979 and 1980. This dispersal caused densities to be similar between shallow and deep water during mid-May during these 2 years. During June and July, newly hatched larvae were found in water up to $21 \mathrm{~m}$ (Jude et al. 1978), suggesting larvae were dispersed into deeper water outside the study area. Similar densities between shallow and open water during June in 1978, 1979, and 1981 resulted from this wide dispersal of rainbow smelt larvae. Larvae occasionally may be returned to shallow areas, causing density there to be significantly higher than in open water, as was observed in June 1980. By late August, young-ofthe-year rainbow smelt resided closer to shore than they did from June to early August. Trawling data indicated that they were most abundant from 6 to $12 \mathrm{~m}$ (Jude et al. 1981).

Rainbow smelt larvae were generally scattered throughout the water column from May to early August. They exhibited no particular pattern of vertical distribution. Wells (1973) reported rainbow smelt larvae showed no strong depth preference, but tended to avoid the surface. During late August, they appeared to concentrate near bottom within the 15-m contour. Large catches of young-of-the-year rainbow smelt in bottom trawls during late August (Jude et al. 1980) substantiated this preference for lower strata. These data were in agreement with Wells (1968) who found that young-of-the-year rainbow smelt in southeastern Lake Michigan concentrated on the bottom during late summer or early fall.

\section{Growth}

The mean length of rainbow smelt larvae collected from early to mid-May was $5.3-6.2 \mathrm{~mm}$. During 1979 this first cohort of rainbow smelt larvae averaged $15.7 \mathrm{~mm}$ long 1 month after hatching. Bigelow and Schroeder (1963) reported a slightly larger size ( 17 or $18 \mathrm{~mm}$ ) for 1-month-old rainbow smelt along the northwestern Atlantic coast. The mean length of rainbow smelt larvae we collected in June may be underestimated due to net avoidance by larger larvae. During late July, rainbow smelt 
we collected ranged from 24 to $47 \mathrm{~mm}$; this is comparable to Lake Huron rainbow smelt, which reached $28-48 \mathrm{~mm}$ during late July (Gordon 1961). The wide size range of young of the year we collected during late August 1978-1981 (26-59 $\mathrm{mm})$ may be due, in part, to the presence of larvae from two cohorts. Mean length of 3-month-old rainbow smelt caught during late August (36.5-4I.1 mm) may be slightly underestimated due to the inclusion of a small number of late-hatched larvae in the August catches. Kendall (1927) reported a larger size $(36.6-63.5 \mathrm{~mm})$ for young-of-the-year rainbow smelt collected in August in Sebago Lake, Maine.

Growth rate of rainbow smelt larvae in the study area during the period 14-16 May to $18-$ 20 June 1979 was approximately $0.30 \mathrm{~mm} /$ day which is comparable to the growth rate of 0.37 $\mathrm{mm} /$ day for their first month of life in southeastern Lake Michigan ( $\mathrm{Jude}_{2}$ et al. 1979). From mid-May to late August 1978-1981, rainbow smelt larvae in the study area appeared to maintain the same growth rate $(0.31-0.36 \mathrm{~mm} /$ day). During summer, however, growth rate may vary considerably. Jude ${ }_{2}$ et al. (1979) reported growth rates of $0.14 \mathrm{~mm} /$ day during July and $0.41 \mathrm{~mm} /$ day during August 1974 .

\section{Acknowledgments}

We thank G. Heufelder, N. Auer, P. Schneeberger, 'T. Rutecki, C. Madenjian, G. Noguchi, S. Klinger, P. Mansfield, L. Flath, J. Braunscheidel, J. Huhn, J. Greiner, and other personnel of the Fishery Laboratory of the Great Lakes Research Division for help in collection of samples and processing of data, and $\mathrm{F}$. Tesar, G. Heufelder, L. Wells, C. Liston, and R. Owens for editorial comments. This work was supported by a contract from Consumers Power Company, Jackson, Michigan. Contribution 364 of the Great Lakes Research Division, University of Michigan.

\section{References}

Bigelow, H. B., ANd W. G. Schroeder. 1963. Family Osmeridae. Pages 533-597 in Fishes of the western North Atlantic, volume I, part 3. Memoirs of the Sears Foundation for Marine Research, New Haven, Connecticut, USA.

Brandt, S. B., J. J. Magnuson, and L. B. Crowder. 1980. Thermal habitat partitioning by fishes in Lake Michigan. Canadian Journal of Fisheries and Aquatic Sciences 37:1557-1564.
Christie, W. J. 1974. Changes in the fish species composition of the Great Lakes. Journal of the Fisheries Research Board of Canada 31:827-854.

Cooper, J. E. 1978. Identilication of eggs, larvae and juveniles of the rainbow smelt, Osmerus mordax, with comparison to larval alewife, Alosa pseudoharengus and gizzard shad, Dorosoma cepedianum. Transactions of the American Fisheries Society 107:56-62.

Daly, R. I., AND L. W. Wiegert. 1958. The smelt are running. Wisconsin Conservation Bulletin 23: $1-2$.

Gordon, W. G. 1961. Food of the American smelt in Saginaw Bay, Lake Huron. Transactions of the American Fisheries Society 90:439-443.

JCDE, D. J., AND Six COAuthors. 1978. Adult and juvenile fish, ichthyoplankton and benthos populations in the vicinity of the J. H. Campbell Power Plant, eastern Lake Michigan, 1977. University of Michigan, Great Lakes Research Division, Special Report 65, Ann Arbor, Michigan, USA.

JCDE 1 , D. J., AND EIGHT COAUThors. 1979. Adult, juvenile and larval fish in the vicinity of the $\mathrm{J} . \mathrm{H}$. Campbell Power Plant, eastern Lake Michigan, I978. University of Michigan, Great Lakes Research Division, Special Report 73, Ann Arbor, Michigan, USA.

JCDE 2 , D. J., AND SIX COAUTHORS. 1979. Inshore Lake Michigan fish populations near the D. C. Cook Nuclear Power Plant during preoperational years $-1973,1974$. University of Michigan, Great Lakes Research Division, Special Report 71, Ann Arbor, Michigan, USA.

JUde, D. J., AND Eight COAUThors. 1980. Adult, juvenile and larval fish populations in the vicinity of the J. H. Campbell Power Plant, eastern Lake Michigan, 1979. University of Michigan, Great Lakes Research Division, Special Report 79, Ann Arbor, Michigan, USA.

JLDE, D. J., AND Eight CoAuthors. 1981. Adult, juvenile and larval fish populations in the vicinity of the J. H. Campbell Power Plant, eastern Lake Michigan, 1977-1980. University of Michigan, Great Lakes Research Division, Special Report 86, Ann Arbor, Michigan, USA.

Kendall, W. C. 1927. The smelts. United States Bureau of Fisheries Bulletin 42:2 I7-375.

Legault, R. O., and C. Delisle. 1968. La fraye d'une population d'eperlans geants, Osmerus eperlanus mordax, au Lac Heney, Comte de Gatineau, Quebec. Journal of the Fisheries Research Board of Canada 25:1813-1830.

Liston, C. R., D. Brazo, J. Bohr, R. Ligman, R. O’Neal, and G. Peterson. 1980. Results of 1978 aquatic research at the Ludington pumped storage power plant on Lake Michigan including entrainment of fish and invertebrates, turbine mortalities, reservoir residence periods of salmonid fishes, netting and hydroacoustic surveys and water currents. Michigan State University, Departmenı of Fisheries and Wildlife, Ludington 
Research Laboratory, 1978 Annual Report, Ludington Project, volume 1, Ludington, Michigan, USA.

Liston, C. R., AND P. I. TACK. 1976. A study of water currents and temperatures in Lake Michigan adjacent to the James H. Campbell Power Plant at Port Sheldon, Michigan. Michigan State University, Department of Fisheries and Wildlife, East Lansing, Michigan, USA.

MacCallum, W. R., and H. A. Regier. 1970. Distribution of smelt, Osmerus mordax and the smelt fishery in Lake Erie in the early 1960's. Journal of the Fisheries Research Board of Canada 27 : 1823-1846.

McKenzie, R. A. 1964. Smelt life history and fishery in the Miramichi River, New Brunswick. Fisheries Research Board of Canada Bulletin 144: $1-77$.

Owens, R. W. 1982. The ecology of spawning smelt in southeastern Lake Michigan. Master's thesis. Eastern Michigan University, Ypsilanti, Michigan, USA.

RUPP, R. S. 1959. Variation in the life history of the American smelt in inland waters of Maine. Transactions of the American Fisheries Society $88: 241-252$.

RuPP, R. S. 1965. Shore spawning and survival of eggs of the American smelt. Transactions of the American Fisheries Society 94:160-168.

Rupp, R. S. 1968. Life history and ecology of the smelt (Osmerus mordax) in inland waters of Maine.
Federal Aid in Fisheries Restoration Project F-10-R, Final Report, Augusta, Maine, USA.

Selgeby J. H., W. R. MacCallum, and D. V. SwedBERG. 1978. Predation by rainbow smelt ( $\mathrm{Os}$ merus mordax) on lake herring (Coregomus artedii) in western Lake Superior. Journal of the Fisheries Research Board of Canada 35:1437-1463.

Stewart, D. J., J. F. Kitchell, and L. B. Crowder 1981. Forage fishes and their salmonid predators in Lake Michigan. Transactions of the American Fisheries Society 110:751-763.

Van Oosten, J. 1940. The smelt, Osmerus mordax (Mitchill). United States Bureau of Fisheries, Great Lakes Fishery Investigations, Ann Arbor, Michigan, USA. (Mimeographed report.)

WeLLs, L. 1968. Seasonal depth distribution of fish in southeastern Lake Michigan. United States Fish and Wildlife Service Fishery Bulletin 67:1-15.

WeLLS, L. 1973. Distribution of fish fry in nearshore waters of southeastern and east-central Lake Michigan, May-August 1972. United States Bureau of Sport Fisheries and Wildlife, Great Lakes Fishery Laboratory, Administrative Report, Ann Arbor, Michigan, USA.

Wells, L., ANd A. L. MCLain. 1973. Lake Michigan: man's effects on native fish stocks and other biota. Great Lakes Fishery Commission Technical Report 20.

Yocum, W. L., And F. J. Tesar. 1980. Sled for sampling benthic fish larvae. Progressive Fish-Culturist 42: 118-119. 